\title{
An energy transduction mechanism used in bacterial flagellar type III protein export
}

Tohru Minamino ${ }^{1,2}$, Yusuke V. Morimoto', Noritaka Hara \& Keiichi Namba

Flagellar proteins of bacteria are exported by a specific export apparatus. Flil ATPase forms a complex with FliH and FliJ and escorts export substrates from the cytoplasm to the export gate complex, which is made up of six membrane proteins. The export gate complex utilizes proton motive force across the cytoplasmic membrane for protein translocation, but the mechanism remains unknown. Here we show that the export gate complex by itself is a proton-protein antiporter that uses the two components of proton motive force, $\Delta \psi$ and $\Delta \mathrm{pH}$, for different steps of the protein export process. However, in the presence of FliH, Flil and FliJ, a specific binding of FliJ with an export gate membrane protein, FlhA, is brought about by the FliH-Flil complex, which turns the export gate into a highly efficient, $\Delta \psi$-driven protein export apparatus.

${ }^{1}$ Graduate School of Frontier Bioscience, Osaka University, Suita, Osaka, Japan. ${ }^{2}$ Precursory Research for Embryonic Science and Technology, Japan Science and Technology Agency, 4-1-8 Honcho, Kawaguchi, Saitama 332-0012, Japan. Correspondence and requests for materials should be addressed to T.M. (email: tohru@fbs.osaka-u.ac.jp) or to K.N. (email: keiichi@fbs.osaka-u.ac.jp). 
$\mathrm{P}$ roton motive force (PMF), the electrochemical potential difference of protons across a biological membrane, is utilized as the energy source of many biological activities, including protein export, ATP synthesis and flagellar motor rotation. PMF consists of two components: the electric potential difference $(\Delta \psi)$ and the proton concentration difference $(\Delta \mathrm{pH})$. Although $\Delta \psi$ and $\Delta \mathrm{pH}$ are equivalent driving forces for proton movement and translocation in physics and have also been believed to have equivalent roles in biological functions, recent experimental data suggest a differential usage of $\Delta \psi$ and $\Delta \mathrm{pH}$ in biological processes, such as flagellar motor rotation ${ }^{1}$ and ATP synthesis ${ }^{2}$.

The bacterial flagellum, which is responsible for motility, consists of at least three substructures: the basal body, the hook and the filament. Flagellar assembly begins with the basal body, followed by the hook and finally the filament. For construction of the flagellum, many of the flagellar component proteins are transported to the distal end of the flagellar structure by the flagellar type III protein export apparatus. The export apparatus consists of three soluble proteins, FliH, FliI and FliJ, and six integral membrane proteins, FlhA, FlhB, $\mathrm{FliO}$, FliP, FliQ and $\mathrm{FliR}^{3-5}$. These components of the export apparatus share substantial sequence and functional similarities with those of the type III secretion system of pathogenic bacteria, which directly inject virulence factors into their host cells ${ }^{6}$. Recently, it has become apparent that FliH, FliI and FliJ are evolutionarily related to components of $\mathrm{F}_{\mathrm{O}} \mathrm{F}_{1}$-ATP synthase, which utilizes PMF for ATP synthesis ${ }^{5,7-9}$.

FliI is an ATPase ${ }^{10}$ and forms a complex with FliH and Flij ${ }^{11-13}$. The rate of the protein export is markedly low in the absence of FliH, FliI and FliJ, although these components are not essential because flagellar formation occasionally occurs in their absence $e^{13-16}$. The FliH-FliI-FliJ complex binds to export substrates and chaperon-substrate complexes in the cytoplasm ${ }^{17,18}$ and delivers them to the docking platform of the export gate made up of the cytoplasmic domains of FlhA and FlhB $\left(\mathrm{FlhA}_{\mathrm{C}} \text { and } \mathrm{FlhB}_{\mathrm{C}} \text {, respectively }\right)^{19,20}$. An association of the substrate-bound $\mathrm{FliH}_{\mathrm{X}}-\mathrm{FliI}_{6}$-FliJ ring complex with the $\mathrm{FlhA}_{\mathrm{C}}-\mathrm{FlhB}_{\mathrm{C}}$ docking platform induces the initial entry of the substrate into the gate ${ }^{15,21}$. The chemical energy derived from ATP hydrolysis by FliI appears to be required for the dissociation of the $\mathrm{FliH}_{\mathrm{X}}-\mathrm{FliI}_{6}-\mathrm{Flij}$ ring complex from the gate ${ }^{22}$. The export gate complex utilizes PMF as an energy source for the unfolding and translocation of export substrates into the central channel of the flagellum ${ }^{15,16}$. Interestingly, it has been shown, albeit qualitatively, that $\Delta \psi$ alone is sufficient to support export in wild-type cells ${ }^{16}$. Thus, it remains unclear how PMF is used as the energy source.

To clarify the roles of the two components of PMF in flagellar protein export, we collapsed $\Delta \psi$ and $\Delta \mathrm{pH}$ separately and analysed flagellar protein export in a wild-type strain of Salmonella enterica and its $\Delta f l i H-f l i I$ bypass mutant whose second-site P28T mutation in FlhB recovers the export efficiency of some substrates to wildtype levels; therefore, flagellar formation increases markedly in the absence of FliH and Flii ${ }^{15}$. We show that the export gate uses the two components of PMF differently for protein export depending on the presence and absence of FliH and FliI. Protein-protein interactions monitored by a pull-down assay using GST affinity chromatography combined with bacterial genetics show that what is required for efficient $\Delta \psi$-driven protein export of the wild-type export apparatus is not FliH and FliI themselves, but instead a specific interaction of FlhA with Flij that is brought about by the docking of the $\mathrm{FliH}_{-} \mathrm{FliI}_{6}$ ring complex to the gate.

\section{Results}

Effects of $\Delta \Psi$ and $\Delta \mathrm{pH}$ on flagellar protein export. To investigate the role of each component of PMF on flagellar protein export in wild-type cells and a $\Delta f l i H$-fliI bypass mutant $[\Delta f l i H$-fli flhB(P28T)], $\Delta \psi$ and $\Delta \mathrm{pH}$ were collapsed individually by treatment with valinomycin in the presence of $\mathrm{KCl}^{16}$ and by adding potassium benzoate ${ }^{23}$, respectively. The $\Delta \psi$ and $\Delta \mathrm{pH}$ were measured using tetramethylrhodamine methyl ester (TMRM) ${ }^{1}$ and a ratiometric $\mathrm{pH}$ indicator protein, $\mathrm{pHluorin}^{24}$, respectively. Because the hookcapping protein $\mathrm{FlgD}$ is one of the export substrates that are secreted at wild-type levels by the $\Delta f l i H$-fli bypass mutant ${ }^{15}$, we analysed the secretion level of FlgD as a representative measure of the export activity (Fig. 1). The $\Delta \psi$ and $\Delta \mathrm{pH}$ measured at different $\mathrm{pH}$ values in the presence and absence of benzoate are shown in Figure 2. In wild-type cells, at an external $\mathrm{pH}$ of 7.0, the secretion level was significantly reduced by discharging $\Delta \psi$ by $20 \mu \mathrm{M}$ valinomycin at $150 \mathrm{mM} \mathrm{KCl} \mathrm{(Fig.} \mathrm{1a} \mathrm{left} \mathrm{panel)} \mathrm{but} \mathrm{was} \mathrm{not} \mathrm{reduced} \mathrm{at} \mathrm{all} \mathrm{by}$ collapsing $\Delta \mathrm{pH}$ by using potassium benzoate (Fig. $1 \mathrm{~b}$ left panel). These results confirmed a previous report ${ }^{16}$ in a more quantitative manner. In contrast, the secretion by the $\Delta f l i H$-fliI bypass mutant was effectively abolished not only by discharging $\Delta \psi$ (Fig. 1a right panel) but also by collapsing $\Delta \mathrm{pH}$ (Fig. $1 \mathrm{~b}$ right panel). Interestingly, neither of the remaining $\Delta \mathrm{pH}$ (0.35, which is equivalent to $24 \mathrm{mV})$ nor $\Delta \psi(81 \mathrm{mV})$ was effective in driving protein export. The intracellular levels of FlgD were not changed by either treatment. Because the total PMF of the fliH-fliI bypass mutant was the same as that of wild-type cells (Fig. 2d), these results indicate that $\Delta \psi$ and $\Delta \mathrm{pH}$ are both essential and are used differently for flagellar protein export in the absence of FliH and FliI.

The acidification of the cytoplasm is known to interfere with flagellar protein export ${ }^{16}$. This relationship raised the possibility that the export apparatus of the bypass mutant may be more sensitive to low intracellular $\mathrm{pH}$ than the apparatus of the wild-type cells. To examine the $\Delta \mathrm{pH}$ dependence of protein export without lowering the intracellular $\mathrm{pH}$, we varied only the external $\mathrm{pH}$ over a range of 6.0-7.5 (Fig. 1c). The intracellular pH did not change significantly over this external $\mathrm{pH}$ range (Fig. $2 \mathrm{~b}$ ). In wild-type cells, the secretion level was constant over this external $\mathrm{pH}$ range (Fig. 1c left panel). However, the secretion level by the $\Delta f l i H$-fli bypass mutant showed a marked dependence on the external $\mathrm{pH}$ and therefore on $\Delta \mathrm{pH}$; it increased on a downward $\mathrm{pH}$ shift from 7.0 to 6.0 and almost diminished by an upward shift to 7.5 where $\Delta \mathrm{pH}$ is nearly zero (Fig. 1c right panel and Fig. 2c). The $\Delta \psi$ did not change significantly over an external $\mathrm{pH}$ range of 6.0-7.5 (Fig. 2a). Because the $\Delta \mathrm{pH}$ component of the PMF was significantly increased by lowering the external pH (Fig. 2c), resulting in an increase in total PMF (Fig. 2d), we conclude that an increase in the $\Delta \mathrm{pH}$ component facilitates flagellar protein export in the $\Delta f l i H$-fliI bypass mutant but not in wild-type cells. We obtained essentially the same results with another fliH-fli bypass mutant ( $\Delta$ fliH-fliI flhA(V404 M)) (Supplementary Fig. S1).

Solvent-isotope effect on flagellar protein export. We next tested whether the rate of proton transfer would affect the rate of protein export. It has been shown that $\mathrm{D}_{2} \mathrm{O}$ affects the high-speed rotation of the proton-driven bacterial flagellar motor at a low load because of a limitation in the rate of proton translocation through the proton channel of the stator ${ }^{25}$. We therefore analysed this solvent-isotope effect on the flagellar protein export. The PMF did not show any changes from replacing $\mathrm{H}_{2} \mathrm{O}$ with $\mathrm{D}_{2} \mathrm{O}$ (data not shown). Although the FlgD-secretion level of the wild-type cells was not affected by $\mathrm{D}_{2} \mathrm{O}$, the secretion level of the $\Delta f l i H$-fli bypass mutant was markedly reduced (Fig. 3). Interestingly, an increase in $\Delta \mathrm{pD}$ by lowering the external $\mathrm{pD}$ enhanced the secretion rate of $\mathrm{FlgD}$ in the bypass mutant in a manner similar to that of the $\Delta \mathrm{pH}$ (Fig. 3). This result suggests that the protein export activity is limited by the rate of proton translocation through the export gate in the absence of FliH and FliI.

Effect of the FlhB(P28T) mutation alone on $\Delta \mathrm{pH}$ dependence. It is thought that the $f h B(\mathrm{P} 28 \mathrm{~T})$ mutation in the absence of $\mathrm{FliH}$ and FliI increases only the probability of the substrate insertion into the gate ${ }^{15}$. To examine the effect of this mutation by itself, we analysed the $\Delta \mathrm{pH}$ dependence of the protein export by the $f h B(\mathrm{P} 28 \mathrm{~T})$ 
a
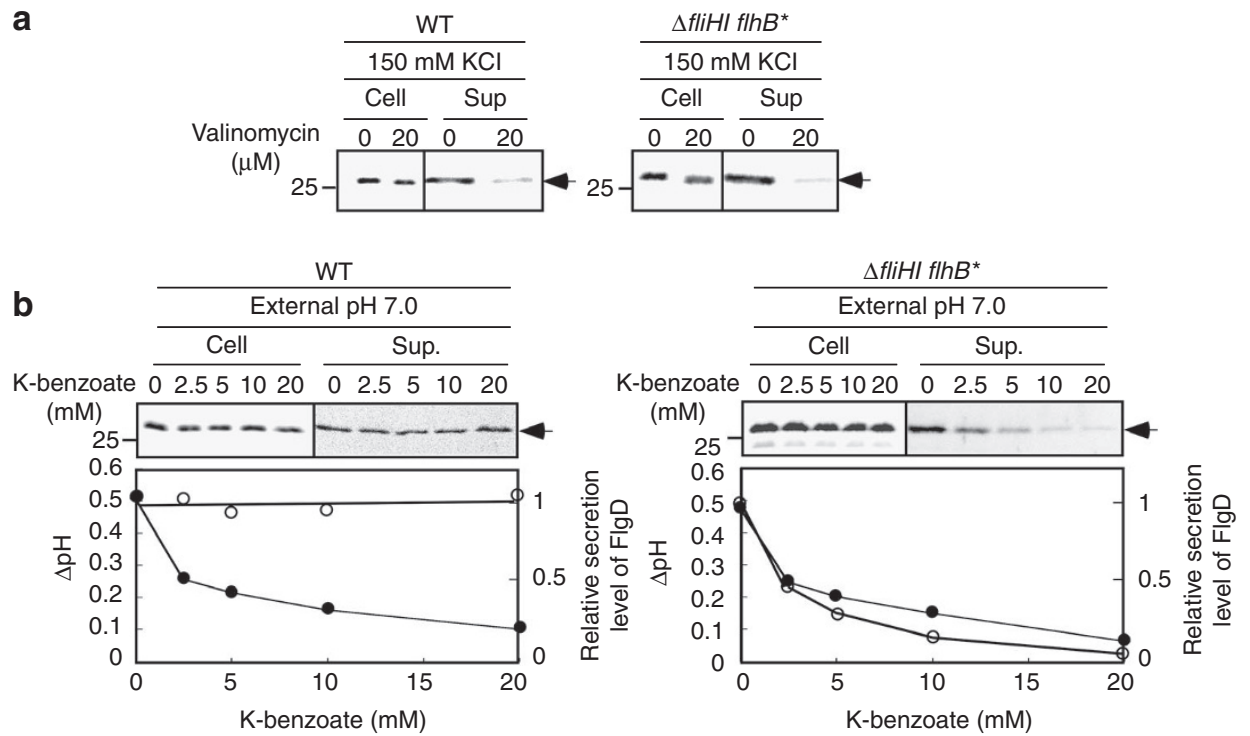

C
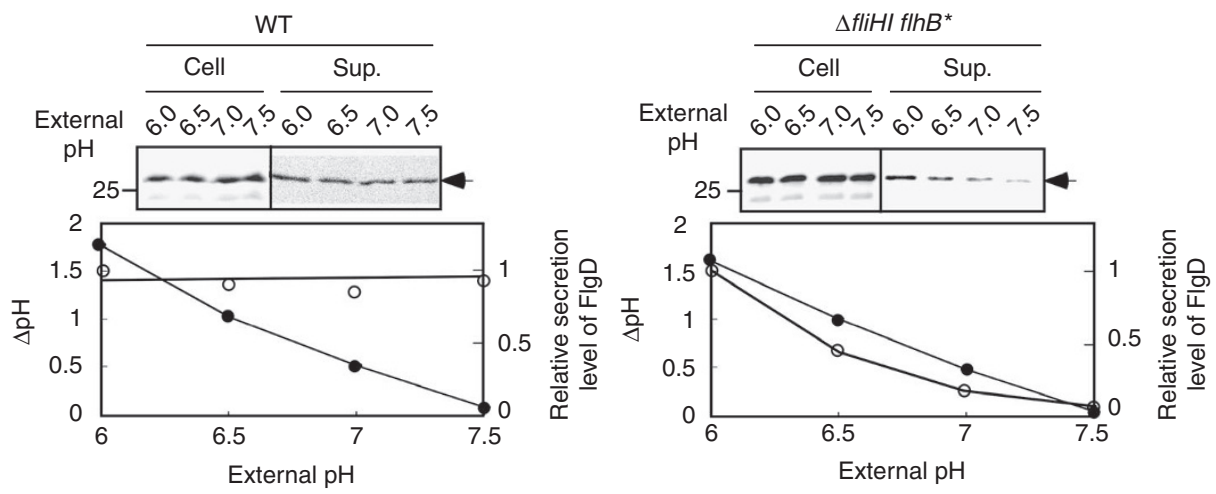

Figure 1 | Effect of $\Delta \Psi$ and $\Delta \mathbf{p H}$ on flagellar protein export. (a) Effect of valinomycin in the presence of $150 \mathrm{mM} \mathrm{KCl}$. Immunoblotting, using polyclonal anti-FlgD antibody, of whole-cell proteins and culture supernatant fractions prepared from SJW1103 (wild-type, indicated as WT) and MMHI0117 ( $\Delta f$ fliHflil flhB(P28T), indicated as $\left.\Delta f l i H I f l h B^{\star}\right)$ grown at $30^{\circ} \mathrm{C}$ in a buffer containing $150 \mathrm{mM} \mathrm{KCl}$ with or without $20 \mu \mathrm{M}$ valinomycin at an external pH of 7.0 .

(b) Effect of potassium benzoate on the secretion level of FlgD (upper panel) and $\Delta \mathrm{pH}$ change (closed circle) and the quantified secretion level of FlgD (open circle; lower panel) at an external pH of 7.0. Intracellular $\mathrm{pH}$ was measured with pHluorin. These data are the average of at least three independent measurements. The experimental errors are less than 10\%. (c) Effect of external pH on FlgD secretion over a pH range of 6.0-7.5.

mutant in the presence of FliH and FliI at an external pH of 7.0. The result was essentially the same as that of the wild-type cells; there was no $\Delta \mathrm{pH}$ dependence (Supplementary Fig. S2). This result confirms that only $\Delta \psi$ is used for protein export in the presence of $\mathrm{FliH}$ and FliI and that, when FliH and FliI are missing, the export gate requires both $\Delta \psi$ and $\Delta \mathrm{pH}$ to couple the energy of the proton influx with protein export.

Effect of FliJ deletion on PMF-driven protein export. FliJ is required for an efficient export process, although it is not essential for export, because occasional flagellar formation is observed in its absence ${ }^{14}$. FliJ enhances the interaction of the FliT-FliD chaperonesubstrate complex with the $\mathrm{N}$-terminal portion of $\mathrm{FlhA}_{\mathrm{C}}{ }^{26}$. Because FlhA is a component of the export gate ${ }^{3-5}$, there is a possibility that FliJ may have a role in the energy transduction mechanism of the flagellar protein export. We therefore analysed the effect of FliJ deletion in the $\Delta f$ liH-fliI bypass mutant at different external $\mathrm{pH}$ values. When FliJ was deleted from the $\Delta f l i H$-fli bypass mutant, the secretion level of FlgD was largely reduced, although not to the level of the $\Delta$ fliH-fliI-fliJ triple null mutant (Fig. $4 \mathrm{a}$ ). This observation indicates that the $\mathrm{FlhB}(\mathrm{P} 28 \mathrm{~T})$ mutation can bypass the FliJ defect to some extent. The deletion of FliJ did not change the response of the $\mathrm{fliH}$ -
fliI bypass mutant to the change in $\Delta \mathrm{pH}$; a downward shift of external pH from 7.0 to 6.0 caused an increase in the secretion level both in the presence and in the absence of FliJ (Fig. 4b). Interestingly, co-overproduction of FliH and FliI in the $\Delta f l i H$-fliI-fliJ flhB(P28T) mutant neither bypassed the motility defect (Fig. 4c) nor recovered the protein export activity (Fig. $4 \mathrm{~d}$ ). The $\Delta \mathrm{pH}$ dependence of the protein export remained even in the presence of FliH and FliI (Fig. 4d). These results clearly indicate that FliJ is the essential component responsible for the $\Delta \psi$-driven protein export by the wild-type export apparatus.

Interaction of FlhA with the soluble proteins. FlhA is composed of an amino-terminal transmembrane domain $\left(\mathrm{FlhA}_{\mathrm{TM}}\right)$ and a carboxy-terminal cytoplasmic domain $\left(\right.$ Flh $\left._{\mathrm{C}}\right)$. Flh $\mathrm{A}_{\mathrm{C}}$ not only forms part of the docking platform for the soluble export components FliI, FliH and FliJ but also is directly involved in the early process of protein export with these soluble components ${ }^{11,21}$. An in-frame deletion of residues 328-351 of FlhA, which is part of the flexible linker between $\mathrm{FlhA}_{\mathrm{TM}}$ and $\mathrm{FlhA}_{\mathrm{C}}{ }^{27}$, results in a loss-of-function phenotype ${ }^{28}$. It has been shown that FliJ binds to the flexible linker ${ }^{26}$, raising the possibility that the loss-of-function phenotype of the FlhA $(\Delta 328-351)$ mutant could result from its impaired 

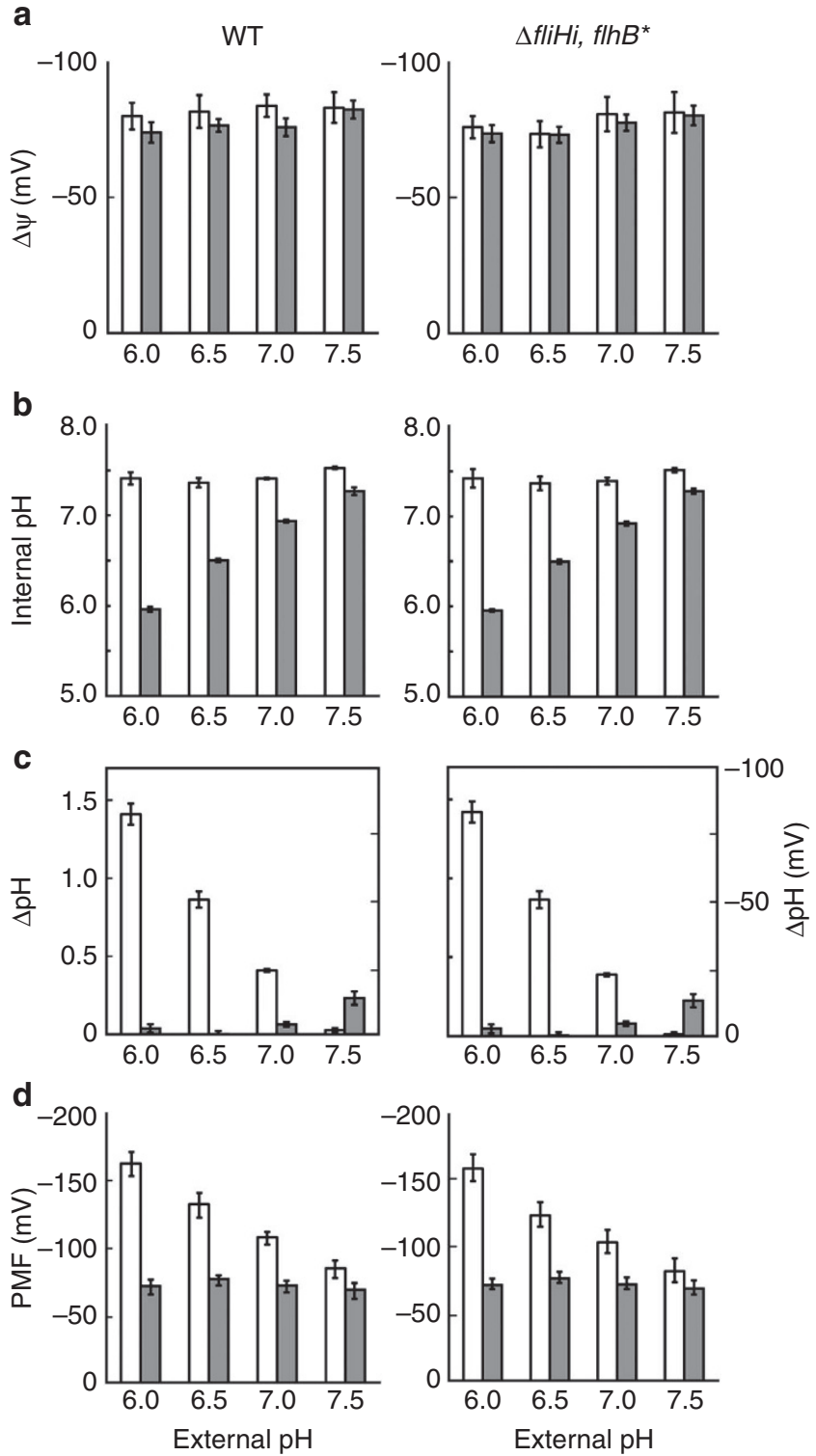

Figure 2 I pH dependence of PMF components. pH dependence of (a) $\Delta \psi$, (b) intracellular $\mathrm{pH},(\mathbf{c}) \Delta \mathrm{pH}$ and (d) total PMF. $\Delta \psi$ was measured in $10 \mathrm{mM}$ potassium phosphate, $0.1 \mathrm{mM}$ EDTA, and $10 \mathrm{mM}$ sodium lactate at an external $\mathrm{pH}$ of $6.0,6.5,7.0$ or 7.5 with (closed bar) or without (open bar) $20 \mathrm{mM}$ potassium benzoate using TMRM. More than 100 cells were measured. Intracellular $\mathrm{pH}$ was measured with $\mathrm{pHluorin}$. At least six independent experiments were conducted. Vertical bars indicate standard deviations.

ability to interact with FliJ. However, it is not yet known whether the linker of FlhA is also involved in the interaction with $\mathrm{FliH}$ and FliI. To test for this possibility, we performed pull-down assays by GST affinity chromatography. We used GST as a negative control. His-FLAG-FlhA copurified with GST-FliH, GST-FliI and GST-FliJ, but not with GST alone (Fig. 5a left panels). His-FLAG-FlhA bound to FliJ with an affinity much higher than its affinity to FliH and FliI. The deletion of residues 328-351 abolished the interaction with FliJ but not with FliH or FliI (Fig. 5a right panels). These results indicate that residues 328-351 of FlhA are the binding target of FliJ but are not the binding target of FliH and FliI.

The P28T mutation of FlhB overcomes the FliH-FliI-FliJ defects to some extent (Fig. 4a). To investigate whether the P28T mutation also suppresses the $\operatorname{FlhA}(\Delta 328-351)$ defect, we transformed a

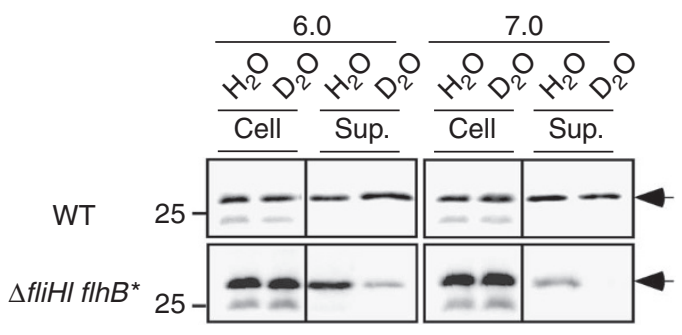

Figure 3 | Solvent-isotope effects on flagellar protein export. Levels of FlgD secreted by the wild-type (WT) and $\Delta f l i H$-flil flhB(P28T) mutant $\left(\Delta f l i H I f l h B^{\star}\right.$ ) cells grown in a buffer containing either $\mathrm{H}_{2} \mathrm{O}$ or $\mathrm{D}_{2} \mathrm{O}$ at external pH levels of 6.0 and 7.0. The level of FlgD secretion was analysed by immunoblotting with the polyclonal anti-FlgD antibody.

$\Delta$ fliH-fliI flhB(P28T) $\Delta$ flhA mutant strain with pTrc99A, pMM108 (His-FLAG-FlhA) or pMM108-1 (His-FLAG-FlhA( $\Delta 328-351)$ ) and analysed the motility of the resulting transformants in soft agar plates (Fig. 5b). His-FLAG-FlhA restored the motility of the $\Delta f l i H$ fli $f l h B(\mathrm{P} 28 \mathrm{~T}) \Delta$ flhA mutant, whereas His-FLAG-FlhA( $\Delta 328-351)$ did not. This result indicates that residues 328-351 of FlhA are critical for the FlhA function even in the $\Delta$ fliH-fliI bypass mutant. Together with the binding of FliJ to residues 328-351 of FlhA (Fig. 5a), these results suggest that a specific conformation of the FlhA linker must be brought about by the proper binding of Flij to residues 328-351 of FlhA to turn the export gate into an efficient, $\Delta \psi$-driven protein export apparatus.

Characterization of a $f(i J(\Delta 13-24)$ mutant. It has been shown that in-frame deletion of residues 13-24 in FliJ considerably reduced the export activity ${ }^{14}$. This raised the possibility that the deletion may affect the interaction with the linker region of FlhA. To test this possibility, we analysed the interaction between FlhA and FliJ $(\Delta 13-$ 24) by pull-down assays. His-FLAG-FlhA did not copurify with

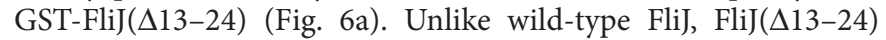
did not restore motility of the $\Delta f l i H$-fliI-fliJ $f l h B(\mathrm{P} 28 \mathrm{~T})$ mutant (Fig. 6b). These results indicate that the reduced export activity of the $f l i J(\Delta 13-24)$ mutant results from the impaired ability of FliJ to interact with the linker of FlhA.

To understand the role of the specific interaction between FliJ and the flexible linker of FlhA in more detail, nine gain-of-function mutants were isolated from the $f(i J(\Delta 13-24)$ mutant. Genetic mapping and DNA sequencing revealed that the second-site mutations are located in the $f l i H$ and $f l i$ genes (Supplementary Fig. S3). These pseudorevertants significantly improved motility although not as well as that of the wild type (Fig. 6c). Most of the flagellar proteins were detected in the culture supernatant of the pseudorevertants (Fig. 6d). In one of the pseudorevertants, MM104H-3 (fliJ( $\Delta 13-24)$ $f i H(\Delta 96-97))$, flagellar proteins were secreted at effectively wildtype levels (Fig. 6d lanes 5 and 7). Consistently, the flagellar hook basal bodies, often with filaments attached, were observed by electron microscopy (data not shown).

To test whether these second-site FliH and FliI mutations also suppress the fliJ-null mutant, we analysed the motility of the $\Delta$ fliH-fli-fliJ triple null mutant transformed with pMMHI001 (FliH + FliI), pMMHI104-3 (FliH( $\Delta 96-97)+$ FliI) or pMMHI104$6(\mathrm{FliH}+\mathrm{FliI}(\mathrm{L} 244 \mathrm{R}))$. These plasmids did not restore the motility of the $\Delta f l i H$-fliI-fliJ triple null mutant at all (Supplementary Fig. S4a), indicating that the second-site mutations do not suppress the fliJ-null mutation.

To test the effect of each second-site mutation by itself on the motility, we isolated the second-site $f l i H$ and fli mutants and analysed their motility. The motility was normal (Supplementary Fig. S4b). As these second-site mutations show no phenotype, they do not appear to affect the function of the FliH and FliI proteins. 
a

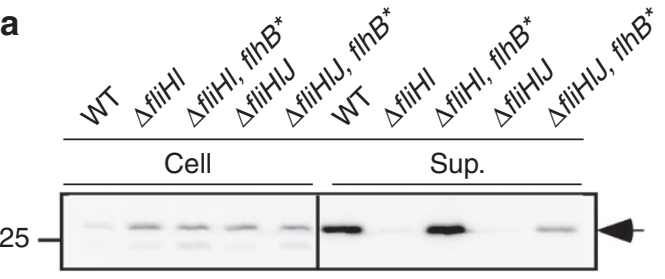

b

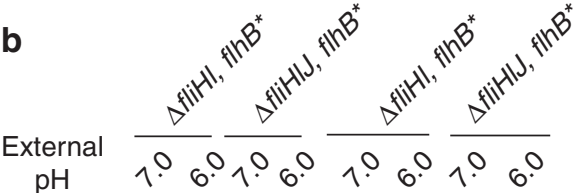

$\mathrm{pH}$

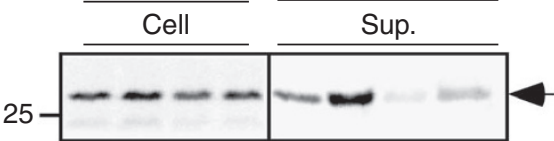

C

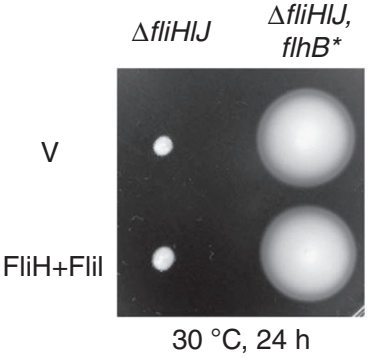

d

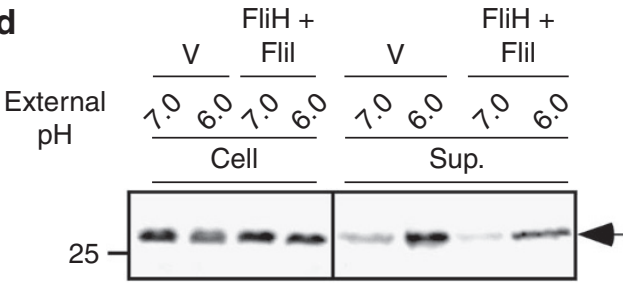

Figure 4 | Effects of FliJ deletion on flagellar protein export.

(a) Immunoblotting, using polyclonal anti-FlgD, of whole-cell proteins and culture supernatant fractions prepared from the wild type (WT), a $\Delta$ fliH-flil double null mutant $(\Delta f l i H I)$, a fliH-flil bypass mutant $\left(\Delta f l i H I f l h B^{\star}\right)$, a fliH-flil-fli triple null mutant $\left(\Delta f\right.$ liHIJ) and a fliH-flil-flis flhB(P28T) ( $\Delta$ fliHIJ flhB $\left.B^{\star}\right)$. (b) Effect of external $\mathrm{pH}$ on FlgD secretion by the $\Delta$ fliHI flh $B^{\star}$ and $\Delta$ fliHIJ flh $B^{\star}$ mutant strains. (c) Motility assays of MMHIJOO1 ( $\Delta$ fliHIJ) and MMHIJO117 ( $\Delta$ fliHIJ $\mathrm{flhB}^{\star}$ ) transformed with pTrc99AFF4 (V) or pMMHI001 (FliH+Flil) in soft agar. The plates were incubated at $30^{\circ} \mathrm{C}$ for $24 \mathrm{~h}$. (d) Effect of external pH on FlgD secretion by the $\Delta$ fliH-flil-fliJ flhB(P28T) mutant strain in the presence and absence of FliH and Flil. Immunoblotting, using polyclonal anti-FlgD antibody, of culture supernatant fractions prepared from MMHIJ0117 carrying pTrc99A or pMMHI001 grown at an external pH of 6.0 and 7.0.

Interaction of FliJ( $\Delta \mathbf{1 3 - 2 4})$ with FliH and FliI. The $f l i(\Delta 13-24)$ mutant caused six extragenic suppressors in FliH and three extragenic suppressors in FliI, raising the possibility that the deletion also affects the interaction with FliH and FliI. Therefore, we analysed the interaction of FliJ $(\Delta 13-24)$ with FliH and FliI by pull-down assays. FliJ $(\Delta 13-24)$ retained the ability to interact with $\mathrm{FliH}$ at wild-type levels and with FliI to an appreciable degree, although not at wildtype levels (Fig. 7a). This observation indicates that the deletion also weakens the FliJ-FliI interaction but not the FliJ-FliH interaction. The suppressor mutations in FliH and FliI did not significantly increase their binding affinity for FliJ $(\Delta 13-24)$ (Fig. $7 \mathrm{~b})$. To test whether the same mutations influence the interaction of FliJ $(\Delta 13-$ 24) with FlhA, we analysed the interaction between FliJ( $\Delta 13-24)$ a

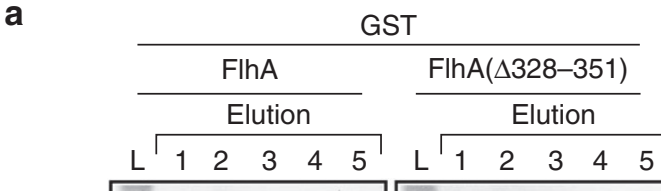

CBB

$\alpha-\mathrm{FlhA}_{\mathrm{c}}$
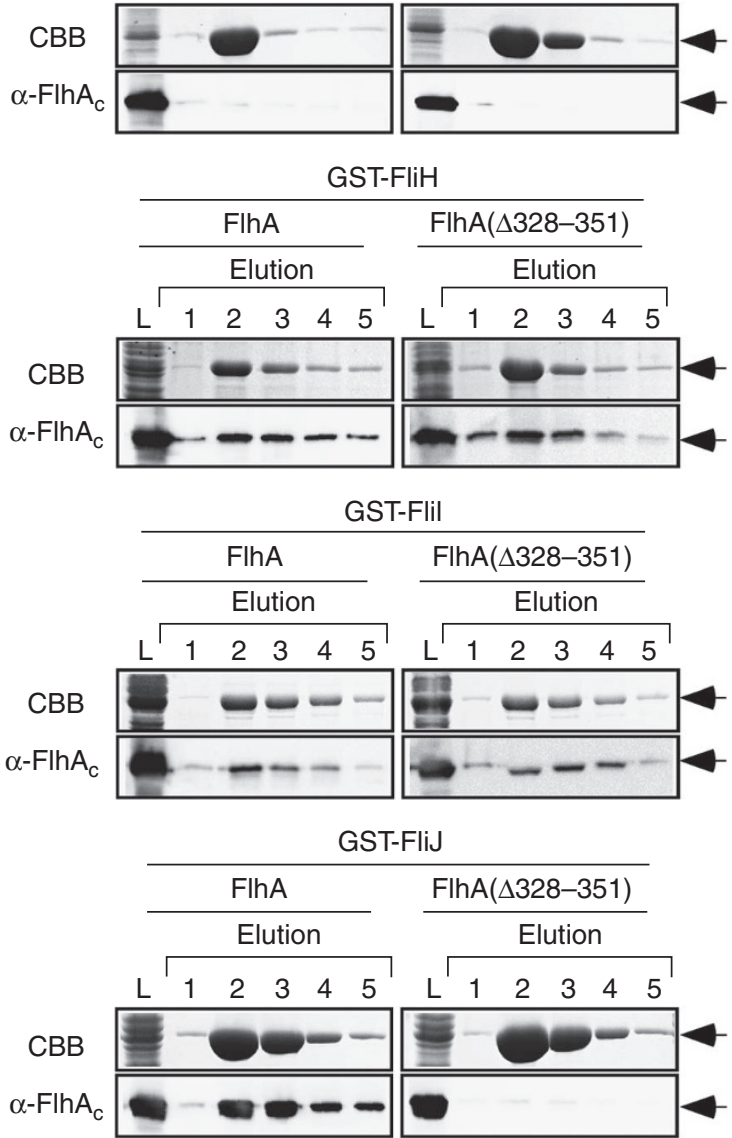

b

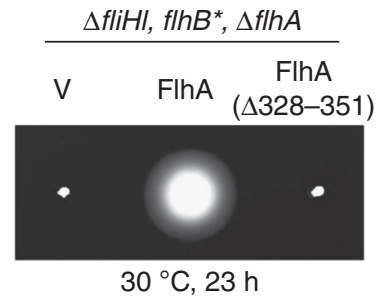

Figure 5 | Effect of a deletion of residues 328-351 of FlhA on the interaction with the soluble proteins. (a) Pull-down assays by GST affinity chromatography. The mixture of the soluble fractions $(L)$ prepared from a $\triangle$ flhDC-cheW mutant expressing GST (first row), GST-FliH (second row), GST-Flil (third row) or GST-FliJ (forth row) with those from a $\triangle$ flhA mutant transformed with pMM108 (N-His-FLAG-FlhA, FlhA) or pMM1081 (N-His-FLAG-FlhA ( $\Delta 328-351)$, FlhA $(\Delta 328-351))$ were loaded onto a GST column. After extensive washing, the proteins were eluted with a buffer containing $10 \mathrm{mM}$ reduced glutathione. The eluted fractions were analysed by CBB staining for GST fusion proteins (upper panels) and immunoblotting with polyclonal anti-FlhA antibody (lower panels). (b) Effect of a $\Delta$ fliH-flil bypass mutation, FlhB(P28T), on the FlhA( $\Delta 328-351)$ mutants. Motility of $\mathrm{NHOOO4}(\Delta \mathrm{flhA} \Delta \mathrm{fliH}$-flil flhB(P28T)) transformed with pTrc99A (V), pMM108 (FlhA) or pMM108-1 (FIhA $(\Delta 328-351)$ ) in soft agar plate. Plates were incubated at $30^{\circ} \mathrm{C}$ for $23 \mathrm{~h}$.

and FlhA in the presence of the suppressor variants of the FliHFliI complex. The suppressor mutation significantly improved the interaction of FliJ( $\Delta 13-24)$ with FlhA (Fig. 7c). 


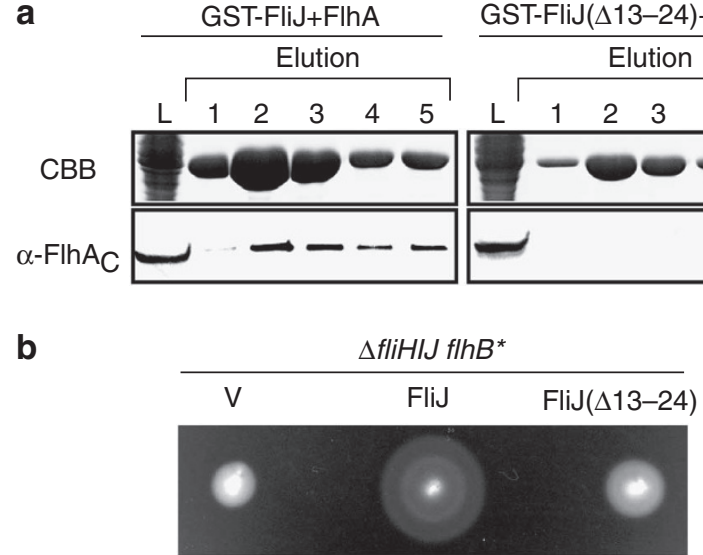

$30{ }^{\circ} \mathrm{C}, 7 \mathrm{~h}$

C

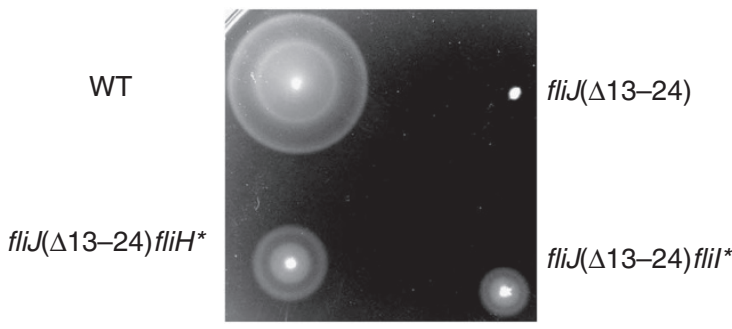

$30{ }^{\circ} \mathrm{C}, 6.5 \mathrm{~h}$

d

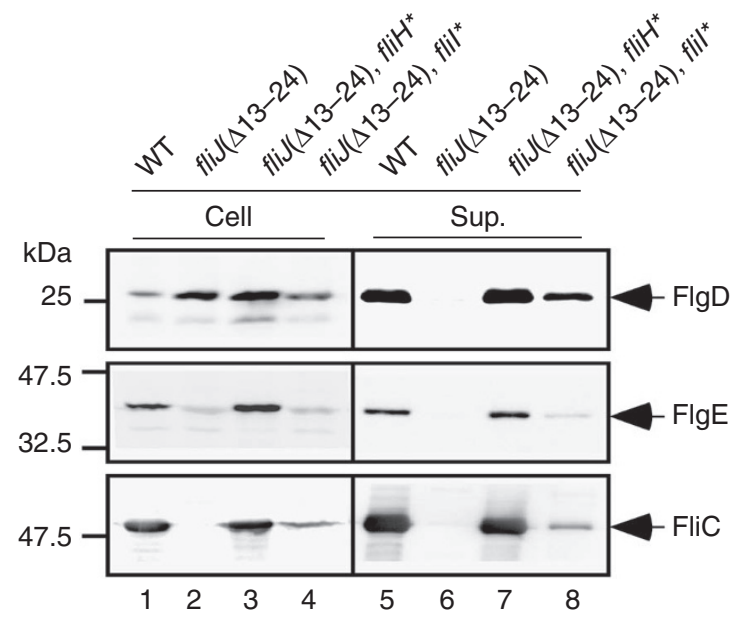

Figure 6 | Effects of a deletion of residues 13-24 in FliJ on the FliJ-FIhA interaction. (a) Pull-down assays by GST affinity chromatography. The eluted factions of GST-FliJ or GST-FliJ( $(13-24)$ were analysed by CBB staining (upper panels), whereas the eluted FlhA protein was detected by immunoblotting with polyclonal anti-FlhA antibody. (b) Motility of a $\Delta f l i H-$ flil-fliJ flhB(P28T) ( $\Delta$ fliHIJ flhB*) mutant transformed with pTrc99AFF4 (V), pMM404 (FliJ) or pRCJ104 (FliJ(A13-24)) in soft agar. The plates were incubated at $30^{\circ} \mathrm{C}$ for $7 \mathrm{~h}$. (c) Motility of pseudorevertants from the fliJ( $\Delta 13-24)$ mutant: wild type (WT), fliJ( $\Delta 13-24)$ mutant and its pseudorevertants (fliJ( $\Delta 13-24), f l i H(\Delta 96-97)$ (labelled as $f_{l i H}{ }^{\star}$ ) and fliJ( $(13-24)$, flil(L244R) (labelled as fli $\left.{ }^{\star}\right)$ ). (d) Secretion analysis of FlgD, FlgE and FliC. Immunoblotting, using polyclonal anti-FlgD, anti-FlgE or antiFliC antibody of whole cell (Cell) and culture supernatant (Sup) fractions prepared from the above strains.

Because FliH and FliI directly bind to $\mathrm{FlhA}_{\mathrm{C}}{ }^{21}$, it is also possible that extragenic suppressor mutations in FliH or FliI might strengthen the FliH-FlhA or FliI-FlhA interaction, respectively, so that the FliJ-FlhA interaction becomes less critical. To test this a

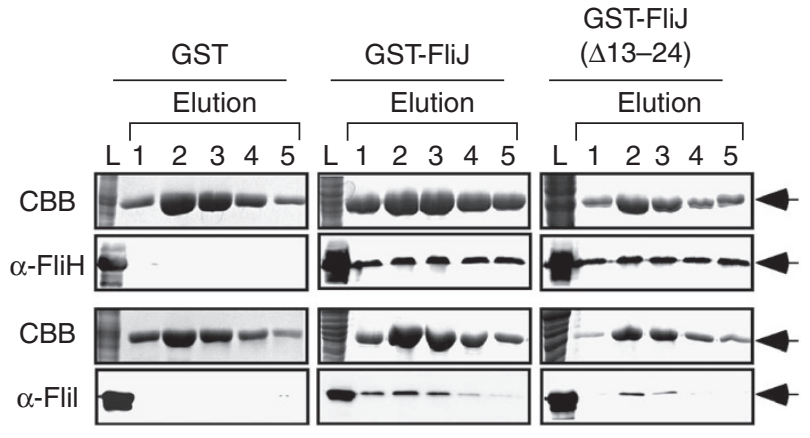

b

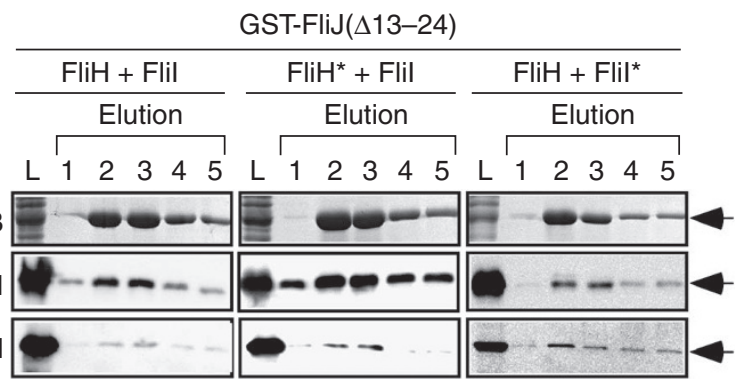

C

\begin{tabular}{|c|c|c|}
\hline GST-FliJ & \multicolumn{2}{|c|}{ GST-FliJ( $(\Delta 13-24)$} \\
\hline FliH + Flil & FliH + Flil & FliH + Flil' \\
\hline Elution & Elution & Elution \\
\hline
\end{tabular}

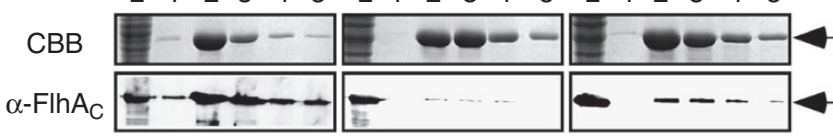

d

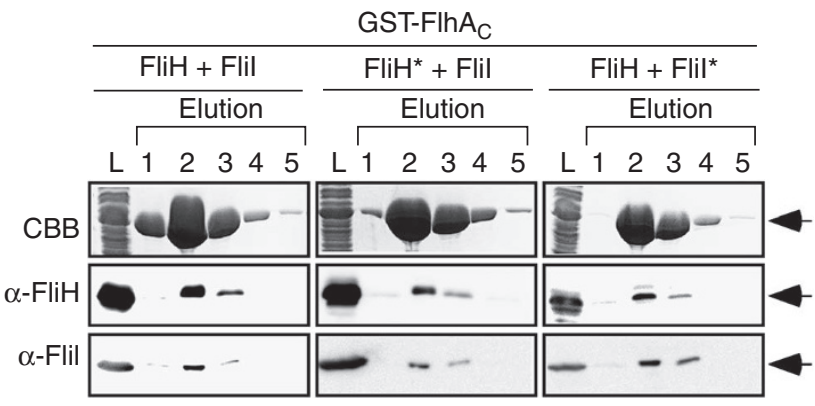

Figure $7 \mid$ Effect of the FliH and Flil suppressor mutations on the interaction of FliJ( $(\mathbf{1 3}-\mathbf{2 4})$ with FlhA. (a) Interactions of FliJ with FliH and Flil. Pull-down assays by GST affinity chromatography. The mixture of the soluble fractions (L) prepared from a $\triangle f / h D C$-cheW mutant expressing GST (left), GST-Flij (middle) or GST-FliJ( $\Delta 13-24$ ) (right) with those from the $\triangle f l h D C$-cheW mutant producing His-FliH or His-Flil were loaded onto a GST column. After extensive washing, proteins were eluted with a buffer containing $10 \mathrm{mM}$ reduced glutathione. (b) Interaction of GST-FliJ( $\Delta 13-24)$ with the wild-type FliH-Flil complex (left) and its suppressor mutant variants (middle, FliH( $\Delta 96-97)+$ Flil; right, FliH + Flil(L244R)).

(c) Interactions of GST-Flij( $(13-24)$ with FlhA in the presence of a suppressor mutant variant of the FliH-Flil complex (FliH + Flil(L244R)). (d) Interaction of GST-Flh $\mathrm{A}_{\mathrm{C}}$ with the suppressor mutant variants of FliH and Flil (FliH ${ }^{\star}$, FliH( $(\Delta 96-97) ;$ Flii ${ }^{\star}$, Flil(L244R)). The eluted fractions were analysed by CBB staining for GST fusion proteins (upper panels) and immunoblotting with polyclonal anti-FliH, anti-Flil or anti-FlhA $A_{c}$ antibody (lower panels).

possibility, we performed pull-down assays. FliH( $(96-97)$ and FliI(L244R) both copurified with GST- FlhA $\mathrm{C}_{\mathrm{C}}$ at the wild-type levels (Fig. 7d), ruling out this possibility. Therefore, we suggest that the pseudorevertants with the second-site mutations are compensat- 
ing for the FliJ( $\Delta 13-24)$ mutation by altering the binding interface between FliJ and the linker of FlhA.

\section{Discussion}

The translocation of proteins across biological membranes requires protein transport machineries that convert biological energies into the mechanical work required for unidirectional protein transport. Nearly all the protein transport systems utilize free energy derived from cycles of nucleoside triphosphate binding and hydrolysis. In addition, PMF contributes to the driving force for protein transport across the bacterial cytoplasmic membrane, the mitochondrial inner membrane and so on ${ }^{29}$. However, the mechanisms of protein translocation across biological membranes by PMF remain obscure.

It is thought that $\Delta \psi$ drives the translocation of negatively charged residues of preproteins across the membrane by an electrophoretic mechanism ${ }^{30-32}$. In contrast, PMF functions on the membrane components of the protein translocation machinery, altering an interaction with SecA ATPase, which uses the energy of ATP binding and hydrolysis to drive preprotein translocation into and across the cytoplasmic membrane ${ }^{33-35}$. Recently, it has been shown that the SecD/SecF complex utilizes PMF to function in the later ATP-independent stages of protein translocation ${ }^{36}$. In mitochondria, where $\Delta \psi$ is the dominant driving force because of its high-level generation during aerobic respiration, the inside negative potential can exert an electrophoretic effect on positively charged polypeptides that are inserted into the membrane. $\Delta \psi$ also activates an inner membrane protein channel of the mitochondrial presequence translocase ${ }^{37}$. Interestingly, it has been shown that $\Delta \psi$ can catalyse protein unfolding during protein translocation ${ }^{38}$. Thus, PMF appears to have multiple roles in protein translocation across the biological membranes.

In this study, we have shown that $\Delta \psi$ alone is sufficient for flagellar protein export in wild-type cells, but both $\Delta \psi$ and $\Delta \mathrm{pH}$ become essential in the absence of FliH and FliI (Fig. 1). These results indicate that the two components of PMF have distinct roles in the flagellar protein export process in the absence of FliH and FliI. This indication suggests that a step of the $\Delta \psi$-dependent export process is different from that powered by $\Delta \mathrm{pH}$. The replacement of $\mathrm{H}_{2} \mathrm{O}$ by $\mathrm{D}_{2} \mathrm{O}$ reduced the level of FlgD secretion in the absence of FliH and FliI but did not reduce it in the wild-type cells (Fig. 3). Lowering the external $\mathrm{pD}$ value from 7.0 to 6.0 increased the secretion levels of FlgD in the absence of FliH and FliI (Fig. 3), indicating that the rate of proton transfer through the export gate determines the overall rate of flagellar protein export by the export gate alone. Taken together, we propose that the flagellar type III export gate complex made up of the six membrane proteins is intrinsically a proton-protein antiporter that requires both $\Delta \psi$ and $\Delta \mathrm{pH}$ as the energy source. Proton transport could be an intrinsic aspect of the mechanism, which is not rate determining in the wild-type export apparatus. This possibility suggests a specific structural mechanism for the essential requirement of both components of the PMF to drive protein export, although the necessary structural information is currently not available.

The deletion of FliJ in addition to the deletion of FliH and FliI further reduced the level of export activity by the export gate but did not alter the $\Delta \mathrm{pH}$-dependent characteristics of the fliH-fliI bypass mutant (Fig. 4b). The export gate still requires $\Delta \mathrm{pH}$ even in the presence of FliH and FliI when FliJ is missing (Fig. 4d). An increase in the $\Delta \mathrm{pH}$ component of PMF significantly facilitated flagellar protein export in the $\Delta$ fliH-fli-fliJ flhB(P28T) mutant (Fig. 4b). Therefore, FliJ appears to be required for the full activation of the export gate complex for efficient, $\Delta \psi$-driven protein export. The FliJ-FlhA interaction with residues 328-351 of FlhA in its linker region and residues 13-24 of FliJ was found to be critical for efficient protein export (Figs. 5 and 6). Because the $f(i J(\Delta 13-24)$ suppressor mutations in FliH or FliI significantly improved the impaired ability of FliJ $(\Delta 13-24)$ to interact with the linker of FlhA (Figs. 6 and 7 ), we propose that FliJ requires support of FliH and FliI to efficiently and properly interact with the linker of FlhA to switch the conformation of the export gate complex into the $\Delta \psi$-driven mode, which appears to be much more efficient than the export gate made up of the six membrane proteins by themselves. The $f l h B(\mathrm{P} 28 \mathrm{~T})$ mutation restored motility of the $\Delta$ fliH-fliI-fliJ triple null mutant to some degree (Fig. 4) but not that of the $\Delta$ fliH-fliI flhA( $\Delta 328-351)$ mutant (Fig. 5), indicating that the linker region of FlhA is essential for flagellar protein export. We propose that a specific conformation of the FlhA linker region brought about by the proper binding of FliJ is critical for the efficient, $\Delta \psi$-driven energy transduction mechanism of flagellar protein export.

It has been proposed that FliJ is not only a general chaperone to prevent premature aggregation of export substrates in the cytoplasm ${ }^{14}$ but also a chaperone escort protein that promotes the cycling of substrate-specific chaperones, FlgN and FliT ${ }^{39}$. The present study, however, has made it clear that FliJ is directly involved in a critical energy-transduction process with FlhA. FliJ facilitates FliI ring formation by binding to the centre of the ring, thereby stimulating the ATPase activity ${ }^{9,39}$. ATP hydrolysis by FliI promotes the disassembly of the FliI ring, presumably for the rapid turnover of the process of substrate delivery and insertion to the export gate ${ }^{15,22}$. Because FliJ binds to the linker of FlhA to fully activate the $\Delta \psi$-driven protein export by the export gate (Fig. 5), we propose that FliJ is a key protein that switches the export gate, which by itself is a low-efficient proton-protein antiporter, into a highly efficient, $\Delta \psi$-driven protein export apparatus. Thus, 'export gate-activator switch' would be a more appropriate name for FliJ.

Why is $\Delta \psi$ alone sufficient for protein export in wild-type cells? It has been shown that the flagellar export apparatus is evolutionarily related to $\mathrm{F}_{0} \mathrm{~F}_{1}$-ATPsynthase, which utilizes PMF and ATP for ATP synthesis and proton pumping, respectively ${ }^{5}$. Although the structural mechanism of the flagellar type III protein export apparatus remains obscure, that of $\mathrm{F}_{\mathrm{o}} \mathrm{F}_{1}$-ATPsynthase is well characterized: the $\alpha / \beta$ subunits form the $\alpha_{3} \beta_{3}$ hexameric ring as the core domain of $\mathrm{F}_{1}$; the $\gamma$ subunit forms the central stalk connecting $\mathrm{F}_{1}$ with $\mathrm{F}_{\mathrm{o}}$ and is rotated within the central hole of the $\alpha_{3} \beta_{3}$ ring by the PMF-driven rotation of the $\mathrm{F}_{\mathrm{o}}$ ring in the membrane; the $\mathrm{b}$ and $\delta$ subunits form the peripheral stalk connecting $\mathrm{F}_{1}$ with $\mathrm{F}_{\mathrm{o}}$, to function as the stator ${ }^{40}$. In many of these aspects, the export apparatus shows similarities with $\mathrm{F}_{\mathrm{o}} \mathrm{F}_{1}$-ATPsynthase: FliI forms a homo-hexamer ring to exert its ATPase activity ${ }^{41,42}$; the structures of FliI and FliJ show extensive structural similarity to the $\alpha / \beta$ subunits $^{8}$ and the $\gamma$ subunit $^{9}$, respectively; FliJ binds to the centre of the FliI ring in a manner similar to the antiparallel $\alpha$-helical-coiled coil formed by the $\mathrm{N}$ - and C-terminal regions of the $\gamma$-subunit penetrating into the central cavity of the $\alpha_{3} \beta_{3}$ ring $^{9}$; the amino-acid sequences of the $\mathrm{N}$ - and $\mathrm{C}$-terminal regions of $\mathrm{FliH}$ are homologous to those of the $\mathrm{b}$ and $\delta$ subunits, respectively ${ }^{7}$; the export gate complex made up of the six integral membrane proteins is powered by PMF across the cytoplasmic membrane $e^{15,16}$. Taken together, it may be possible that the export gate complex utilizes free energy derived from ATP hydrolysis by the $\mathrm{FliH}_{\mathrm{X}}-\mathrm{FliI}_{6}$-FliJ ring complex for efficient proton translocation through the proton channel of the gate complex. Because the export gate by itself functions as a proton-protein antiporter, the proton translocation mechanism of the gate may also be similar to that of $\mathrm{F}_{\mathrm{o}} \mathrm{F}_{1}$-ATPsynthase. However, because the present study has clearly shown that one of the important roles of the FliH-FliI ring complex is to bring FliJ to the FlhA linker region to switch the export gate from a low-efficient proton-protein antiporter to a highly efficient, $\Delta \psi$-driven protein export apparatus, the structural similarity between the two systems in their entire assemblies may be used solely to achieve distinct mechanisms for their distinct functions. The detailed structural information of the entire export apparatus is essential for the mechanistic understanding of the flagellar protein export process in detail. 
Table 1 | Strains and plasmids used in this study.

\begin{tabular}{|c|c|c|}
\hline $\begin{array}{l}\text { Strains and } \\
\text { plasmids }\end{array}$ & $\begin{array}{l}\text { Relevant } \\
\text { characteristics }\end{array}$ & $\begin{array}{l}\text { Source or } \\
\text { reference }\end{array}$ \\
\hline \multicolumn{3}{|l|}{ Salmonella } \\
\hline SJW1103 & $\begin{array}{l}\text { Wild type for motility and } \\
\text { chemotaxis }\end{array}$ & 44 \\
\hline SJW1368 & $\begin{array}{l}\Delta(\text { cheW-flhD }) \text {; master operon } \\
\text { mutant }\end{array}$ & 49 \\
\hline SJW104 & $f l i J(\Delta 13-24)$ & 14 \\
\hline MKM40 & $\Delta$ flij & 20 \\
\hline MMHI001 & $\Delta$ fliH-flil & 42 \\
\hline MMHIJ001 & $\Delta f l i H-f l i l-f l i J$ & This study \\
\hline MMHIJ0117 & $\Delta$ fliH-flil-flis flhB(P28T) & This study \\
\hline $\begin{array}{l}\text { MM104H-xx } \\
\text { series }\end{array}$ & $\begin{array}{l}\text { fliJ }(\Delta 13-24) \text { fliH } \\
\text { pseudorevertants from SJW104 }\end{array}$ & This study \\
\hline $\begin{array}{l}\text { MM104I-xx } \\
\text { series }\end{array}$ & $\begin{array}{l}\text { fliJ( } \Delta 13-24) \text { flil pseudorevertants } \\
\text { from SJW104 }\end{array}$ & This study \\
\hline NH001 & $\Delta f / h A$ & 50 \\
\hline $\mathrm{NHOO4}$ & $\Delta f l i H$-flil flhB(P28T) $\Delta f / h A$ & 50 \\
\hline \multicolumn{3}{|l|}{ Plasmids } \\
\hline $\mathrm{p} \operatorname{Trc99A}$ & Expression vector & GE Healthcare \\
\hline pGEX-6p-1 & Expression vector & GE Healthcare \\
\hline pGKK1702 & pGEX-6p-1/GST-Flil & 22 \\
\hline pMM104 & pET19b/His-FlhA $A_{c}$ & 11 \\
\hline pMM108 & pTrc99A/His-FLAG-FIhA & 28 \\
\hline pMM108 & $\begin{array}{l}\mathrm{p} \operatorname{Trc} 99 \mathrm{~A} / \mathrm{His}-\mathrm{FLAG}-\mathrm{FlhA}(\Delta 328- \\
\text { 351) }\end{array}$ & 28 \\
\hline pMMHA003 & pET19b/His-FlhA $A_{c} 38 \mathrm{~K}$ & 28 \\
\hline pMMHA1001 & pGEX-6p-1/GST-FIhA $A_{c}$ & 20 \\
\hline pMM306 & pTrc99A/His-FliH & 11 \\
\hline pMM404 & pTrc99AFF4/FliJ & 11 \\
\hline pMMJ1001 & pGEX6p-1/GST-FliJ & 20 \\
\hline pMM1702 & pTrc99A/His-Flil & 11 \\
\hline pMMHI001 & pTrc99AFF4/FliH + Flil & 15 \\
\hline pTIH001 & pGEX6p-1/GST-FliH & 21 \\
\hline pRCJ104 & pTrc99AFF4/FliJ(413-24) & 14 \\
\hline pMMHI104-3 & pTrc99AFF4/FliH( $\Delta 96-97)+$ Flil & This study \\
\hline pMMHI104-6 & pTrc99AFF4/FliH + Flil(L244R) & This study \\
\hline pMMJ1002 & pGEX6p-1/GST-FliJ(413-24) & This study \\
\hline pYVM001 & pKK223-3/pHluorin(M153R) & 47 \\
\hline
\end{tabular}

\section{Methods}

Bacterial strains and media. Salmonella strains and plasmids used in this study are listed in Table 1. L-broth (LB) and soft tryptone agar plates were prepared as described in refs 11,43 . Motility medium contained $10 \mathrm{mM}$ potassium phosphate, $0.1 \mathrm{mM}$ EDTA and $10 \mathrm{mM}$ sodium lactate. The $\mathrm{pH}$ value of each motility medium was adjusted to the desired $\mathrm{pH}$ by the addition of $\mathrm{HCl}$ or $\mathrm{KOH}$ in the presence or absence of potassium benzoate. Ampicillin was added to LB to a final concentration of $100 \mu \mathrm{g} \mathrm{ml}^{-1}$.

DNA manipulations and transductional crosses. DNA manipulations were performed as described before ${ }^{28}$. P22-mediated transductional crosses were performed with p22HTint as described in ref. 44.

Construction of the Salmonella deletion mutants. A $\Delta$ fliH-fli-fliJ triple null mutant and a $\Delta$ fliH-fliI-fliJ flhB(P28T) mutant were constructed using the $\lambda$-red homologous recombination system ${ }^{45}$.

Motility assay. Fresh colonies were inoculated on soft tryptone agar plates and incubated at $30^{\circ} \mathrm{C}$. At least five independent experiments were conducted.

Secretion assay. The cells were grown with shaking in $5 \mathrm{ml}$ of $\mathrm{LB}$ at $30^{\circ} \mathrm{C}$ until the cell density had reached an $\mathrm{OD}_{600}$ of $\sim 1.0$ and were washed twice with the motility buffer at $\mathrm{pH}$ 7.0. To test the effect of $\Delta \psi$ on flagellar protein export, we used valinomycin as described in ref. 16. To test the effects of $\Delta \mathrm{pH}$ on the export, the cells were resuspended in the $5-\mathrm{ml}$ motility buffer at $\mathrm{pH} 6.0,6.5,7.0$ or 7.5 in the presence and absence of potassium benzoate and incubated at $30^{\circ} \mathrm{C}$ for $1 \mathrm{~h}$. To test the $\mathrm{D}_{2} \mathrm{O}$ effect, the cells were resuspended in the 5-ml motility buffer prepared in $\mathrm{D}_{2} \mathrm{O}$ and incubated at $30^{\circ} \mathrm{C}$ for $1 \mathrm{~h}$. Cultures were centrifuged to obtain cell pellets and culture supernatants. Cell pellets were resuspended in the SDS-loading buffer, followed by normalization to a cell density to yield a constant amount of cells.
Proteins in the culture supernatants were precipitated using $10 \%$ trichloroacetic acid, suspended in the Tris/SDS loading buffer and heated at $95^{\circ} \mathrm{C}$ for $5 \mathrm{~min}$. After SDS-PAGE, immunoblotting with polyclonal anti-FlgD, anti-FlgE and anti-FliC antibodies was performed as described before ${ }^{43}$. Detection was performed with an ECL immunoblotting detection kit (GE Healthcare). At least three independent secretion assays were performed.

Measurement of the membrane potential. The membrane potential was measured as described by Lo et al. ${ }^{1}$. Cells were suspended in motility medium plus $10 \mathrm{mM}$ EDTA for $20 \mathrm{~min}$. Cells were washed with motility medium and incubated in motility medium containing $0.1 \mu \mathrm{M}$ TMRM (Invitrogen) for $10 \mathrm{~min}$ at room temperature. To observe bacterial cell bodies and epifluorescence of TMRM, we used an inverted fluorescence microscope (IX-71, Olympus) with a $\times 150$ oil immersion objective lens (UApo150XOTIRFM, NA 1.45, Olympus) and an electronmultiplying charged-coupled device camera (C9100-02, Hamamatsu Photonics), as described before ${ }^{46}$. Calculation of the membrane potential was performed as described in ref. 1, with minor modifications. More than 100 wild-type cells and a $\mathrm{fliH}$-fliI bypass mutant were measured at various external $\mathrm{pH}$ values with or without $20 \mathrm{mM}$ potassium benzoate.

Intracellular pH measurement. Intracellular $\mathrm{pH}$ measurements of wild-type cells and a $\Delta$ fliH-fliI bypass mutant transformed with pYVM001, which encodes pHluorin(M153R) on pKK223-3 (ref. 47), were recorded at various external $\mathrm{pH}$ values with or without potassium benzoate, as described previously ${ }^{48}$. The fluorescence-excitation spectra of the wild-type and $\Delta$ fli $H$-fliI bypass mutant cells expressing pHluorin(M153R) were recorded on a fluorescence spectrophotometer (RF-5300PC, Shimadzu). The 410/470-nm excitation ratios were calculated and converted to $\mathrm{pH}$ values based on the calibration curve. At least six independent measurements were recorded.

Pull-down assays by GST affinity chromatography. The soluble fractions prepared from SJW1364 ( $\Delta$ flhDC-cheW) expressing GST-FliH, GST-FliI, GST-FliJ,

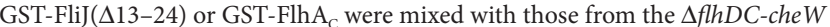
mutant transformed with pMM108 (His-FLAG-FlhA), pMM108-1 (His-FLAGFlhA( $\Delta 328-351)$ ), pMM306 (His-FliH), pMM1702 (His-FliI), pMM406 (His-FliJ), pMMHI001 (FliH + FliI), pMMHI104-3 (FliH( $\Delta 96-97)+$ FliI) or pMMHI104-6 $(\mathrm{FliH}+\mathrm{FliI}(\mathrm{L} 244 \mathrm{R}))$ were loaded onto a glutathione Sepharose 4B column (bed volume, $1 \mathrm{ml}$; GE Healthcare). After the column was extensively washed with $25 \mathrm{ml}$ of PBS ( $8 \mathrm{~g}$ of NaCl, $0.2 \mathrm{~g}$ of $\mathrm{KCl}, 3.63 \mathrm{~g}$ of $\mathrm{Na}_{2} \mathrm{HPO}_{4} \cdot 12 \mathrm{H}_{2} \mathrm{O}, 0.24 \mathrm{~g}$ of $\mathrm{KH}_{2} \mathrm{PO}_{4}$, $\mathrm{pH} 7.4$, per litre), proteins were eluted with $50 \mathrm{mM}$ Tris- $\mathrm{HCl}, \mathrm{pH} 8.0$, and $10 \mathrm{mM}$ reduced glutathione. Fractions containing GST, GST-FliH, GST-FliI, GST-FliJ, GST-FliJ $(\Delta 13-24)$ or GST-FlhA $_{C}$ were identified by SDS-PAGE with Coomassie brilliant blue $(\mathrm{CBB})$ staining and immunoblotting with polyclonal anti-FlhA $\mathrm{A}_{\mathrm{C}}$, antiFliH or anti-FliI antibody. Detection was performed with an ECL immunoblotting detection kit (GE Healthcare). At least three independent pull-down assays were performed.

\section{References}

1. Lo, C. J., Leake, M. C., Pilizota, T. \& Beryy, R. M. Nonequivalence of membrane voltage and ion-gradient as driving forces for the bacterial flagellar motor at low load. Biophys. J. 93, 294-302 (2007).

2. Wiedenmann, A., Dimroth, P. \& von Ballmoos, C. Functional asymmetry of the $\mathrm{F}_{0}$ motor in bacterial ATPsynthases. Mol. Microbiol. 72, 479-490 (2009).

3. Macnab, R. M. How bacteria assemble flagella. Annu. Rev. Microbiol. 57, 77-100 (2003).

4. Minamino, T. \& Namba, K. Self-assembly and type III protein export of the bacterial flagellum. J. Mol. Microbiol. Biotechnol. 7, 5-17 (2004).

5. Minamino, T., Imada, K. \& Namba, K. Mechanisms of type III protein export for bacterial flagellar assembly. Mol. Biosyst. 4, 1105-1115 (2008).

6. Cornelis, G. R. The type III secretion injectisome. Nat. Rev. Microbiol. 4, 811-825 (2006)

7. Pallen, M. J., Bailey, C. M. \& Beatson, S. A. Evolutionary links between FliH/YscL-like proteins from bacterial type III secretion systems and secondstalk components of the FoF1 and vacuolar ATPases. Protein Sci. 15, 935-941 (2006).

8. Imada, K., Minamino, T., Tahara, A. \& Namba, K. Structural similarity between the flagellar type III ATPase FliI and $\mathrm{F}_{1}$-ATPase subunits. Proc. Natl Acad. Sci. USA 104, 485-490 (2007).

9. Ibuki, T., Imada, K., Minamino, T., Kato, T., Miyata, T. \& Namba, K. Common architecture between the flagellar protein export apparatus and F- and VATPases. Nat. Struct. Mol. Biol. 18, 277-282 (2011).

10. Fan, F. \& Macnab, R. M. Enzymatic characterization of FliI: an ATPase involved in flagellar assembly in Salmonella typhimurium. J. Biol. Chem. 271, 3198131988 (1996)

11. Minamino, T. \& Macnab, R. M. Interactions among components of the Salmonella flagellar export apparatus and its substrates. Mol. Microbiol. 35, 1052-1064 (2000).

12. Minamino, T. \& Macnab, R. M. FliH, a soluble component of the type III flagellar export apparatus of Salmonella, forms a complex with FliI and inhibits its ATPase activity. Mol. Microbiol. 37, 1494-1503 (2000). 
13. González-Pedrajo, B., Fraser, G. M., Minamino, T. \& Macnab, R. M. Molecular dissection of Salmonella FliH, a regulator of the ATPase FliI and the type III flagellar protein export pathway. Mol. Microbiol. 45, 967-982 (2002).

14. Minamino, T., Chu, R., Yamaguchi, S. \& Macnab, R. M. Role of FliJ in flagellar protein export in Salmonella. J. Bacteriol. 182, 4207-4215 (2000).

15. Minamino, T. \& Namba, K. Distinct roles of the FliI ATPase and proton motive force in bacterial flagellar protein export. Nature 451, 485-488 (2008).

16. Paul, K., Erhardt, M., Hirano, T., Blair, D. F. \& Hughes, K. T. Energy source of flagellar type III secretion. Nature 451, 489-492 (2008).

17. Thomas, J., Stafford, G. P. \& Hughes, C. Docking of cytosolic chaperonesubstrate complexes at the membrane ATPase during flagellar type III protein export. Proc. Natl Acad. Sci. USA 101, 3945-3950 (2004).

18. Imada, K., Minamino, T., Kinoshita, M., Furukawa, Y. \& Namba, K. Structural insight into the regulatory mechanisms of interactions of the flagellar type III chaperone FliT with its binding partners. Proc. Natl Acad. Sci. USA 107, 8812-8817 (2010)

19. Minamino, T., Gonzalez-Pedrajo, B., Kihara, M., Namba, K. \& Macnab, R. M. The ATPase FliI can interact with the type III flagellar protein export apparatus in the absence of its regulator, FliH. J. Bacteriol. 185, 3983-3988 (2003).

20. Minamino, T., Yoshimura, S. D., Morimoto, Y. V., González-Pedrajo, B., Kami-ike, N. \& Namba, K. Roles of the extreme N-terminal region of FliH for efficient localization of the FliH-FliI complex to the bacterial flagellar type III export apparatus. Mol. Microbiol. 74, 1471-1483 (2009).

21. Minamino, T. et al. Role of the C-terminal cytoplasmic domain of FlhA in bacterial flagellar type III protein export. J. Bacteriol. 192, 1929-1936 (2010).

22. Kazetani, K., Minamino, T., Miyata, T., Kato, T. \& Namba, K. ATP-induced Fli hexamerization facilitates bacterial flagellar protein export. Biochem. Biophys. Res. Commun. 388, 323-327 (2009).

23. Minamino, T., Imae, Y., Oosawa, F., Kobayashi, Y. \& Oosawa, K. Effect of intracellular $\mathrm{pH}$ on rotational speed of bacterial flagellar motors. J. Bacteriol. 185, 1190-1194 (2003)

24. Miesenbock, G., Angelis, D. A. D. \& Rothman, J. E. Visualizing secretion and synaptic transmission with $\mathrm{pH}$-sensitive green fluorescent proteins. Nature 394, 192-195 (1998).

25. Chen, X. \& Berg, H. C. Solvent-isotope and $\mathrm{pH}$ effects on flagellar rotation in Escherichia coli. Biophys. J. 78, 2280-2284 (2000).

26. Bange, G., Kümmerer, N., Engel, C., Bozkurt, G., Wild, K. \& Sinning, I. FlhA provides the adaptor for coordinated delivery of late flagella building blocks to the type III secretion system. Proc. Natl Acad. Sci. USA 107, 11295-11300 (2010).

27. Saijo-Hamano, Y. et al. Structure of the cytoplasmic domain of FlhA and implication for flagellar type III protein export. Mol. Microbiol. 76, 260-268 (2010).

28. Saijo-Hamano, Y., Minamino, T., Macnab, R. M. \& Namba, K. Structural and functional analysis of the C-terminal cytoplasmic domain of FlhA, an integral membrane component of the type III flagellar protein export apparatus in Salmonella. J. Mol. Biol. 343, 457-466 (2004).

29. Wickner, W. \& Schekman, R. Protein translocation across biological membrane. Science 310, 1452-1456 (2005)

30. Cao, G., Kuhn, A. \& Dalbey, R. E. The translocation of negatively charged residues across the membrane is driven by the electrochemical potential: evidence for an electrophoresis-like membrane transfer mechanism. EMBO J. 14, 866-875 (2004).

31. Delgado-Partin, V. M. \& Dalbey, R. E. The proton motive force, acting on acidic residues, promotes translocation of amino-terminal domains of membrane proteins when the hydrophobicity of the translocation signal is low. J. Biol. Chem. 273, 9927-9934 (1998).

32. Schuenemann, T. A., Delgado-Nixon, V. M. \& Dalbey, R. E. Direct evidence that proton motive force inhibits membrane translocation of positively charged residues within membrane proteins. J. Biol. Chem. 274, 6855-6864 (1999).

33. Nouwen, N., de Kruijff, B. \& Tommassen, J. prlA suppuressors in Escherichia coli relieve the proton electrochemical gradient dependency of the translocation of wild-type precursors. Proc. Natl Acad. Sci. USA 93, 5953-5957 (1996).

34. Nishiyama, K., Fukuda, A., Morita, K. \& Tokuda, H. Membrane deinsertion of SecA underlying proton motive force-dependent stimulation of protein translocation. EMBO J. 18, 1049-1058 (1999).

35. Mori, H. \& Ito, K. Biochemical characterization of a mutationally altered protein translocation: proton motive force stimulation of the initiation phase of translocation. J. Bacteriol. 185, 405-412 (2003).

36. Tsukazaki, T. et al. Structure and function of a membrane component SecDF that enhances protein export. Nature 474, 235-238 (2011).
37. van der Laan, M., Hutu, D. P. \& Rehling, P. On the mechanism of preprotein import by the mitochondrial presequence translocase. Biochim. Biophys. Acta. 1803, 732-739 (2010).

38. Huang, S., Ratliff, K. S. \& Matouschek, A. Protein unfolding by the mitochondrial membrane potential. Nat. Struct. Biol. 9, 301-307 (2002).

39. Evans, L. D., Stafford, G. P., Ahmed, S., Fraser, G. M. \& Hughes, C. An escort mechanism for cycling of export chaperones during flagellum assembly. Proc. Natl Acad. Sci. USA 103, 17474-17479 (2006).

40. Yoshida, M., Muneyuki, E. \& Hisabori, T. ATP synthase-a marvellous rotary engine of the cell. Nat. Rev. Mol. Cell Biol. 2, 669-677 (2001).

41. Claret, L., Susannah, C. R., Higgins, M. \& Hughes, C. Oligomerisation and activation of the FliI ATPase central to bacterial flagellum assembly. $\mathrm{Mol}$. Microbiol. 48, 1349-1355 (2003).

42. Minamino, T. et al. Oligomerization of the bacterial flagellar ATPase FliI is controlled by its extreme N-terminal region. J. Mol. Biol. 360, 510-519 (2006).

43. Minamino, T. \& Macnab, R. M. Components of the Salmonella flagellar export apparatus and classification of export substrates. J. Bacteriol. 181, 1388-1394 (1999).

44. Yamaguchi, S., Fujita, H., Sugata, K., Taira, T. \& Iino, T. Genetic analysis of H2, the structural gene for phase-2 flagellin in Salmonella. J. Gen. Microbiol. 130, 255-265 (1984)

45. Datsenko, K. A. \& Wanner, B. L. One-step inactivation of chromosomal genes in Escherichia coli K-12 using PCR products. Proc. Natl Acad. Sci. USA 97, 6640-6645 (2000).

46. Morimoto, Y. V., Nakamura, S., Kami-ike, N., Namba, K. \& Minamino, T. Charged residues in the cytoplasmic loop of MotA are required for stator assembly into the bacterial flagellar motor. Mol. Microbiol. 78, 1117-1129 (2010).

47. Morimoto, Y. V., Kojima, S., Namba, K. \& Minamino, T. M153R mutation in a $\mathrm{pH}$-sensitive green fluorescent protein stabilizes its fusion proteins. PLoS One 6, e19598 (2011)

48. Morimoto, Y. V., Che, Y- S., Minamino, T. \& Namba, K. Proton-conductivity assay of plugged and unplugged MotA/B proton channel by cytoplasmic pHluorin expressed in Salmonella. FEBS Lett. 584, 1268-1272 (2010).

49. Ohnishi, K., Ohto, Y., Aizawa, S- I., Macnab, R. M. \& Iino, T. FlgD is a scaffolding protein needed for flagellar hook assembly in Salmonella typhimurium. J. Bacteriol. 176, 2272-2281 (1994).

50. Hara, N., Namba, K. \& Minamino, T. Genetic characterization of conserved charged residues in the bacterial flagellar type III export protein FlhA. PLoS One 6, e22417 (2011)

\section{Acknowledgements}

We acknowledge M. Kihara for continuous support and encouragement, and M. Kinoshita-Minamino and Y. Abe for technical assistance. Y.V.M. and N.H. are research fellows of the Japan Society for the Promotion of Science. This work was supported in part by Grants-in-Aid for Scientific Research (22570161 and 23121516 to T.M., and 21227006 to K.N.) and Targeted Proteins Research Program from the Ministry of Education, Culture, Sports, Science and Technology of Japan and by Takeda Science Foundation (to T.M.)

\section{Author contributions}

T.M. and K.N. conceived and designed the experiments. T.M., Y.V.M. and N.H. conducted the experiments. T.M. and Y.V.M. analysed the data. T.M. and K.N. wrote the paper.

\section{Additional information}

Supplementary Information accompanies this paper at http://www.nature.com/ naturecommunications

Competing financial interests: The authors declare no competing financial interests.

Reprints and permission information is available online at http://npg.nature.com/ reprintsandpermissions/

How to cite this article: Minamino, T. et al. An energy transduction mechanism used in bacterial flagellar type III protein export. Nat. Commun. 2:475 doi: 10.1038/ncomms1488 (2011).

License: This work is licensed under a Creative Commons Attribution-NonCommercialShare Alike 3.0 Unported License. To view a copy of this license, visit http:// creativecommons.org/licenses/by-nc-sa/3.0/ 